\author{
Vladimir G usak ${ }^{1}$, Igor Drozdnik ${ }^{2}$, Vladimir Shmalko and Yuriy Kaftan ${ }^{2}$
}

\title{
INFLUENCE OF COKE QUENCHING METHOD ON ITS REACTIVITY
}

\author{
1M ETINVEST Holding, 130, Artema str., 83048 Donetsk, Ukraine \\ 2 Ukrainian State Research Institute of Carbochemistry, 7, Vesnina str., 61023 Kharkov, Ukraine
}

Received: August 15, 2011 / Revised: August 31, 2011 / Accepted: October 30, 2011

(C) Gusak V., Drozdnik I., Shmalko V., Kaftan Y., 2012

\begin{abstract}
The results of investigation for the influence of the coke quenching method on the coke reactivity were shown. Using thermogravimetry and scanning electron microscopy significant differences of the porous structure and peculiarities of the structure of coke carbon, which forms the pores walls in both wet and dry quenching coke, were discovered. It was established that higher reactivity of wet quenching coke is due to its higher porosity $(60 \%$ higher than that of dry quenching coke).
\end{abstract}

Keywords: coke, structure, wet quenching, dry quenching, TGA, SEM, pores.

\section{Introduction}

Reactive power and postreactive strength became one of the main quality measures of blast furnace coke quality in the world practice, as it reflects its behavior in blast furnace process most effectively, especially with the use of pulverized coal injection method (PCI). Injecting up to $200 \mathrm{~kg}$ of coal per ton of crude iron increases the time of charge in the blast furnace almost twice [1]. It results in low reactive power.

Most frequently reactive power is measured by the method of ("Nippon Steel Corporation") - NSC, diagnosing reactive index (CRI) and coke postreactive strength (CSR) or "hot" strength [2]. In this regard, Western European and Northern American metallurgic plants impose high requirements to the coke quality according to the following indices: CSR - more than $60 \%$ and CRI - less than $30 \%$.

Coke reactive index level and coke postreactive strength is known to be mainly provided by the properties of carbon raw material source. Nevertheless, some other factors, including out-of-furnace processing [3] can influence CRI and CSR.

One of the technological operations in coke processing is coke quenching done in wet or dry way. It was found out that stamp blends coke which was dry quenched in dry quenching chambers of coke plant with other equal conditions (charge content, preparation and coking technological regime) is characterized by lower rate of CRI and higher rate of CSR than wet quenched coke [4]. studied.

In our work cokes from the usual coal blends are

\section{Experimental}

For the study of the factors determining the abovementioned difference, wet quenched and dry quenched coke was produced at the Public Company "Avdeevskiy Coking Plant" from the charge of the following content (Table 1).

This blend had the following characteristics: $A^{d}=8.9, S^{d}{ }_{t}=1.34, V^{d a f}=32.7 \%, y=15 \mathrm{~mm}$.

Dry and wet quenched coke from this blend was tested for quality measures, strength index, actual and apparent density and reactive capacity according to allUnion state standard 10089-89 and Ukrainian national standardization system 4703:2006 (ISO 18894:2006).

Thermogravimetric analysis ${ }^{1}$ was performed with the use of derivatograph "Paulic-Paulic-Erdey" mark Q1500 with computer control and logging system. Temperature and weight loss was registered with the computer once a second. The software allows printing derivatograms or exporting them to hard disc drive in .png file format.

Dynamic thermogravimetric analysis was performed in inert medium (with Ar purity $99.9 \%$ ). Oxidation thermogravimetry was performed in air medium. The research was done in the temperature range of 293$1273 \mathrm{~K}$ and with the heating rate of $10 \mathrm{~K} / \mathrm{min}^{-1}$. Accuracy of temperature regulation is $\pm 1 \mathrm{~K}$. Sample weight is $350-400 \mathrm{mg}$. Reference substance is incinerated aluminum oxide. Gas purging speed is $0.51 / \mathrm{min}$. Air purging is done with microprocessor through U-tube with $\mathrm{CaCl}_{2}$.

Statistical analysis of experimental data was performed with the help of ORIGIN 8.0.

1 Thermogravimetric analysis was performed by senior researcher Tolmachev N.V. 
Rank and component composition of coal blend

\begin{tabular}{|c|c|c|c|}
\hline Name of the supplier & Coal rank & $\begin{array}{l}\text { Content in } \\
\text { charge }\end{array}$ & $\begin{array}{l}\text { Total for } \\
\text { rank }\end{array}$ \\
\hline Processing plant «Samsonovskaya» + Processing plant «Selidovskaya» & \multirow{3}{*}{ Gas coals } & 16 & \multirow{3}{*}{36} \\
\hline Processing plant «Zarechnaya» & & 14 & \\
\hline Promugolservis & & 6 & \\
\hline Processing plant «Mikhailovskaya» & \multirow{4}{*}{ Fat coals } & 8 & \multirow{4}{*}{34} \\
\hline Processing plant «Dzerzhinskaya» + Processing plant «Mikhailovskaya» & & 8 & \\
\hline Processing plant «Samsonovskaya + Processing plant «Dzerzhinskaya» & & 9 & \\
\hline Processing plant «Duvanskaya» + Processing plant «Kievskaya» & & 9 & \\
\hline Kolosnikovskaya & \multirow{2}{*}{$\begin{array}{l}\text { Close-burning } \\
\text { coals }\end{array}$} & 16 & \multirow{2}{*}{21} \\
\hline Open-pit mine «Neryungrinskaya» (No.1) & & 5 & \\
\hline Processing plant «Sholokhovskaya» & \multirow{2}{*}{ Semi-lean coals } & 5 & 5 \\
\hline Processing plant «Uzlovskaya» & & 4 & 4 \\
\hline
\end{tabular}

Table 2

Proximate analysis, coke strength and density indices

\begin{tabular}{|c|c|c|c|c|c|c|c|c|c|c|}
\hline \multirow{2}{*}{ Coke } & \multicolumn{3}{|c|}{ Technical analysis, $\%$} & \multicolumn{2}{|c|}{ Strength index } & \multirow{2}{*}{ 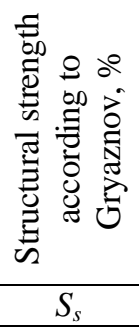 } & \multirow{2}{*}{ 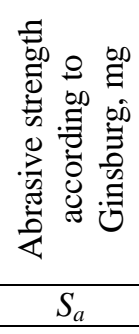 } & \multirow{2}{*}{ 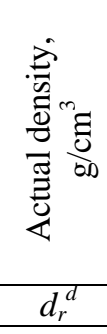 } & \multirow{2}{*}{ 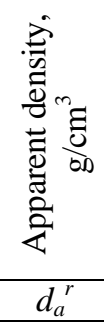 } & \multirow{2}{*}{ 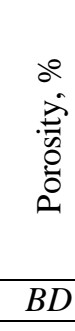 } \\
\hline & $A^{d}$ & $S_{t}^{d}$ & $V^{\text {daf }}$ & $M_{25}$ & $M_{10}$ & & & & & \\
\hline No.1 & 13 & 1.27 & 0.9 & 86.2 & 8.6 & 87 & 102 & 1.923 & 1.026 & 46.7 \\
\hline No.2 & 12.9 & 1.20 & 0.1 & 87.6 & 7.9 & 87 & 104 & 1.924 & 1.024 & 46.8 \\
\hline
\end{tabular}

Table 3

Reactive index of wet quenching and dry quenching coke

\begin{tabular}{|c|c|c|c|}
\hline \multirow{2}{*}{ Coke } & \multicolumn{3}{|c|}{ Coke reactive index } \\
\cline { 2 - 4 } & $\begin{array}{c}\text { According to all-Union state } \\
\text { standard 10089-89, } \mathrm{cm}^{3} / \mathrm{g} \cdot \mathrm{s}\end{array}$ & \multicolumn{2}{|c|}{$\begin{array}{r}\text { According to Ukrainian national standardization } \\
\text { system 4703:2006 }\end{array}$} \\
\cline { 2 - 4 } & & CRI \% & CSR, \% \\
\hline No.1 (wet quenching) & 0.28 & 54.6 & 25.0 \\
\hline No.2 (dry quenching) & 0.24 & 50.9 & 28.2 \\
\hline
\end{tabular}

\section{Results and Discussions}

Results of coke No.1 (wet quenched) and coke No.2 (dry quenched) analysis are shown in Tables 2 and 3.

Less devolatization from dry quenched coke can be explained by its long holding in dry quenching coke plant prechamber at the high temperature, which was close to the one at which coke was poked out from the coking chamber.

Coking proved the known fact of lower mechanic strength $\left(M_{25}\right.$ and $\left.M_{10}\right)$ of wet quenched coke in comparison with dry quenched coke.
Less mechanical strength $\left(M_{25}\right)$ for wet quenched coke can be explained by heat shock at its quenching with water, leading to additional crack formation, which takes place in a Micum-drum. Besides, it can be the result of higher porosity and probably of the Rebinder effect, which, as is widely known, results in solid body strength decrease due to the presence of absorbed water in pores.

Other indices of coke properties, given in the Table 2 , do not show any significant differences between wet quenched and dry quenched coke.

At the same time reactive index of wet quenched and dry quenched coke from the same coal blend differ a 
lot according to all-Union state standard 10089-89 and CRI index (Table 3). It can happen because of the difference of porous structure or because of the difference in chemical activity of the carbon, forming pores walls.

However, as it can be seen in Table 2, porosity, estimated as difference quotient of actual and apparent actual density for both types of coke has almost the same rate. Probably, ethanol molecule used for picnometric analysis does not penetrate all pores formed in the process of wet coke quenching and makes it necessary to measure its porosity in some other way, for example, by the water absorbed in pores. Thus, according to the data [5], estimated value of ethanol and water absorption platform is 23.1 and $10.5 \mathrm{~nm}^{2}$, respectively.

Therefore, matching data from Table 2 and 3 allows to suppose that the data received from measuring actual and apparent density do not reflect real picture of wet and dry quenched coke porosity and other more informative methods are required.

Thermogravimetry experiments turned out to be more informative with coke samples being heated. Thermogravimetry allowed defining the following indices that characterize structural and thermochemical properties of cokes studied. These are pores capacity with respect to moisture $W\left(\mathrm{mg} \mathrm{H}_{2} \mathrm{O} / \mathrm{g}\right.$ coke) and coke ignition initiation temperature (according to oxidation thermogravimetry).

For thermoplastic records of coke samples, see Fig. 1. Coke porous structure was evaluated by moisture volume, kept by coke, i.e. assuming that coke pores volume is equal to the volume of absorbed moisture.

For porosity tests coke samples dried to constant weight at $423 \mathrm{~K}$ were prepared. After cooling down to room temperature, the samples were put into an exiccator with a vessel filled with water on the bottom. Coke samples were held in moist environment at room temperature for $15 \mathrm{~h}$. After that part of the samples were taken (after thorough mixing) for tests on derivatograph.

Based on the derivatogramme processing results the following data were received (Table 4).

As it is seen from the data in Table 4, pores volume of wet quenching coke (coke No.1) is by $66 \%$ higher than that of dry quenched coke. Coke No.1 has lower burning point that equals to $775 \mathrm{~K}$ and is by 26 degrees lower than that of dry quenched coke (coke No.2).
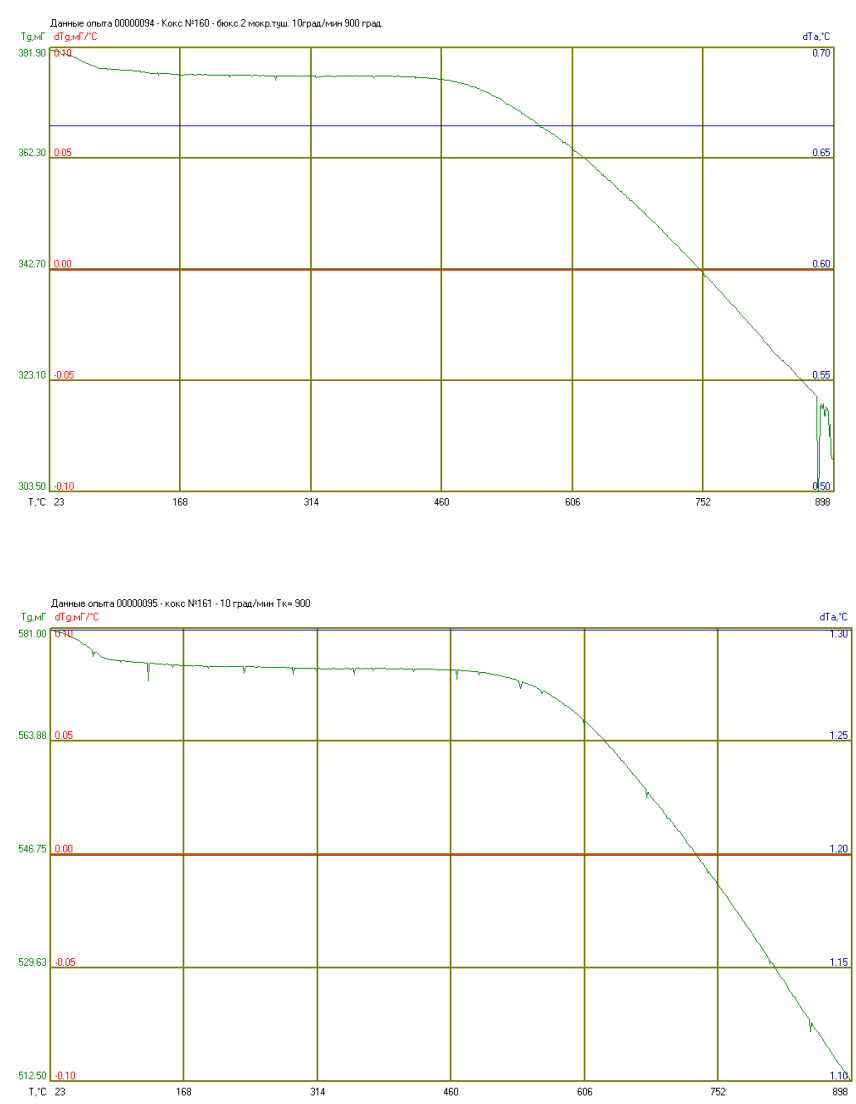

Fig. 1. Thermoplastic records of wet quenching (above) and dry quenching (below) coke samples

Oxidation thermogravimetry allows to measure coke reactive power relative to oxygen. Table 4 shows data for the speed of coke weight loss due to reaction with oxygen in the air (furnace loss rate). It is seen that wet quenched coke has higher reactive power relative to oxygen than dry quenched coke.

Thus, the conducted thermogravimetric researches allowed to discover considerable differences in the porosity of dry quenched and wet quenched coke, which were not detected when measuring actual and apparent density with the use of picnometer method.

Besides, different chemical activity of the pores surfaces for the studied cokes was discovered.

Table 4

Values, characterizing coke porosity and its thermochemical properties

\begin{tabular}{|c|c|c|c|c|}
\hline \multirow{2}{*}{ Coke } & \multicolumn{4}{|c|}{ Coke thermochemical properties } \\
\cline { 2 - 5 } & $\begin{array}{c}\text { Dehydration } \\
\text { temperature } \\
\left(T_{d, \mathrm{H} 2 \mathrm{O})}\right), \mathrm{K}\end{array}$ & $\begin{array}{c}\text { Inflaming } \\
\text { temperature } \\
(T i), \mathrm{K}\end{array}$ & $\begin{array}{c}\text { Pores volume } \\
\text { according to water } \\
\text { capacity }(W), \mathrm{ml} / \mathrm{g}\end{array}$ & $\begin{array}{c}\text { Furnace loss } \\
\text { speed }(V), \\
\mathrm{g} \cdot \mathrm{s}^{-1} \cdot 10^{-5}\end{array}$ \\
\hline №1 (wet quenched) & 354 & 502 & 16.0 & 2.6 \\
\hline №2 (dry quenched) & 358 & 528 & 10.6 & 1.8 \\
\hline
\end{tabular}


For characterizing coke porous structure peculiarities and pores wall structure the method of scanning electron microscopy (SEM) was used. Scanning electron microscope Jeol JSM 840 gave pictures of coke cleavage surface with different level of magnification: 100x, 500x, 2500x, 5000x, and 10000x (Figs. 2 and 3).

It was established that wet quenched coke has the minimum pores size of 0.6 micron and the maximum of about 30 micron. Minimum wall thickness is 0.8 micron and maximum thickness is more than 10 microns.

Dry quenched coke has the minimum pores size of about 0.7 micron and the maximum of about 30 microns. The minimum pores wall thickness is 1.6 micron, which is twice as much as for wet quenched coke, and the maximum thickness is more than 10 microns.
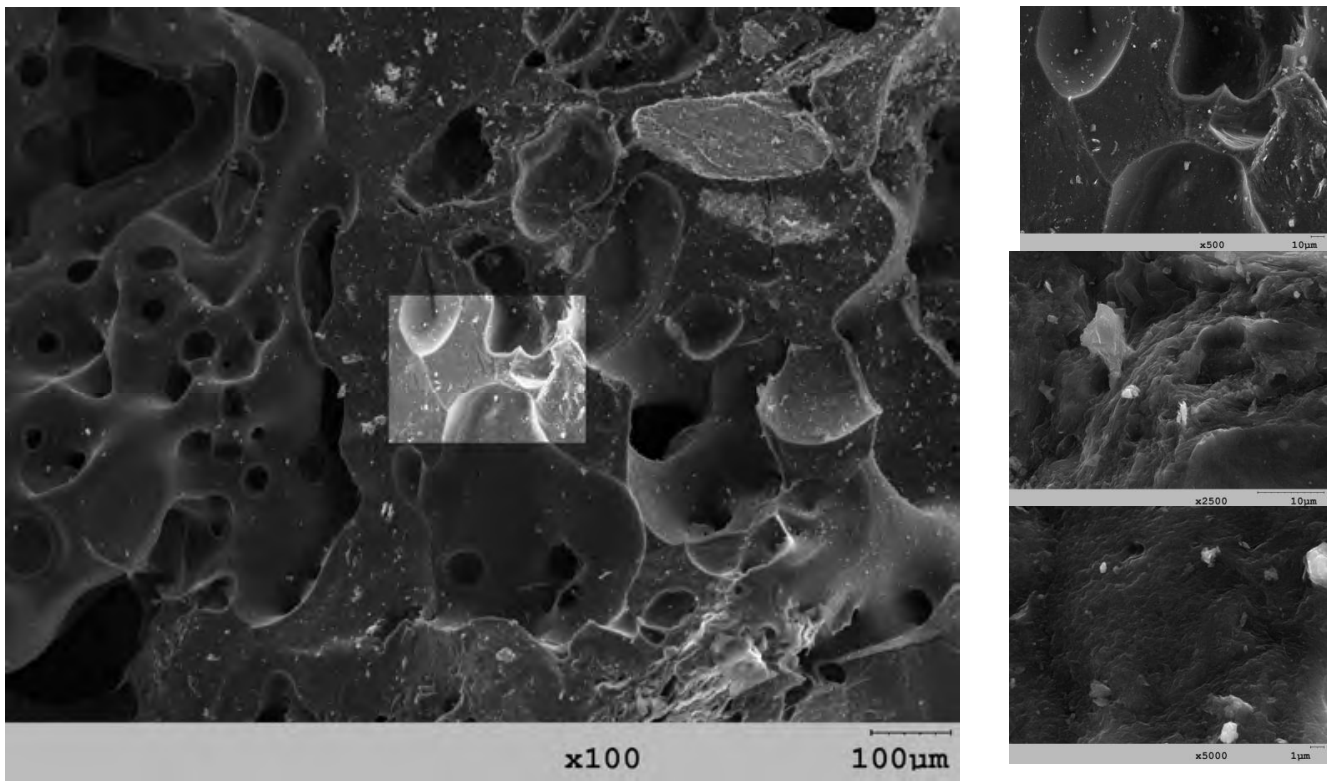

Fig. 2. Pores walls of wet quenching coke (SEM, 100x); clarified area is represented rightward with 500x, 2500x and 5000x magnification
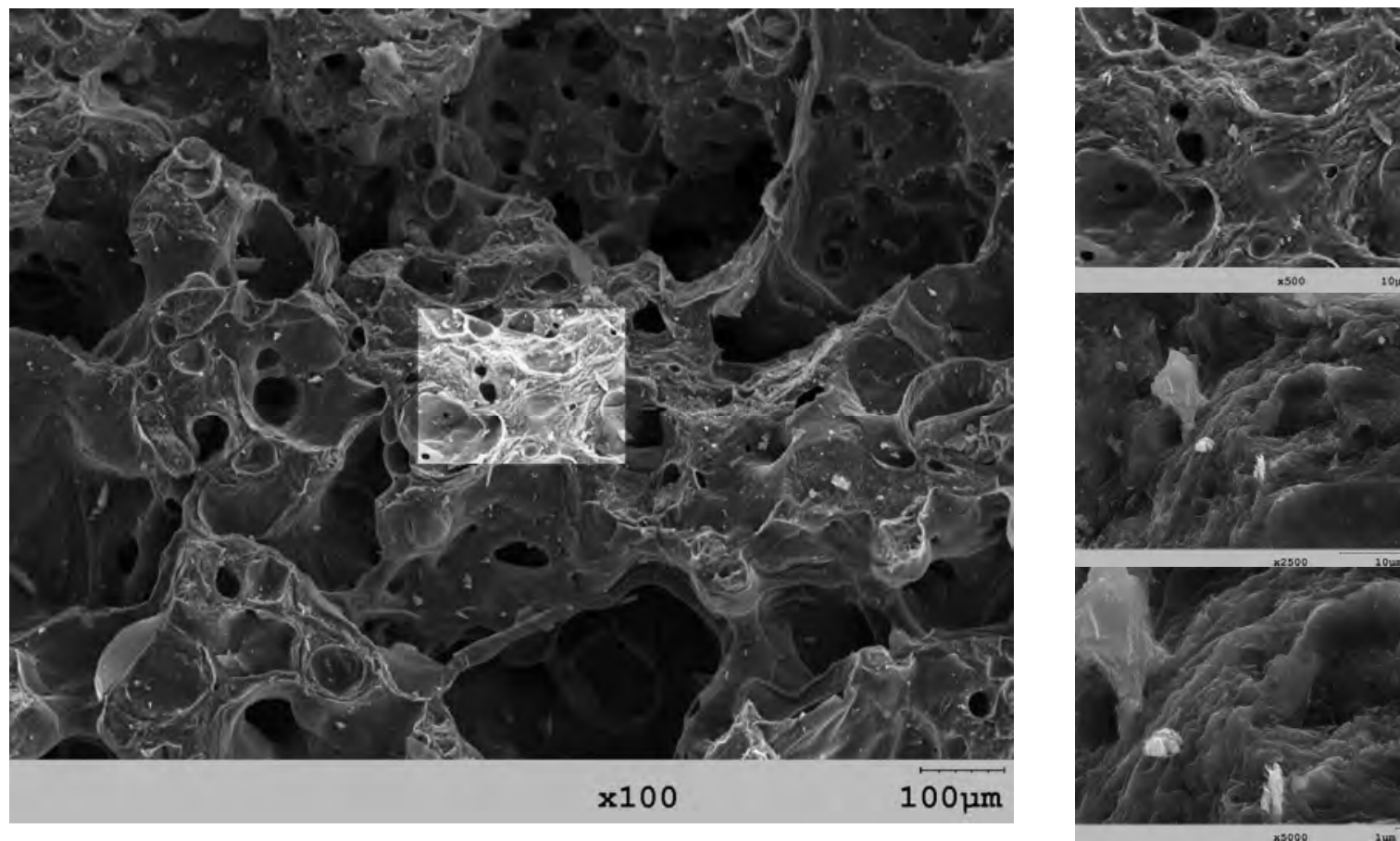

Fig. 3. Pores walls of dry quenching coke (SEM, 100x); clarified area is represented rightward with 500x, 2500x and 5000x magnification 


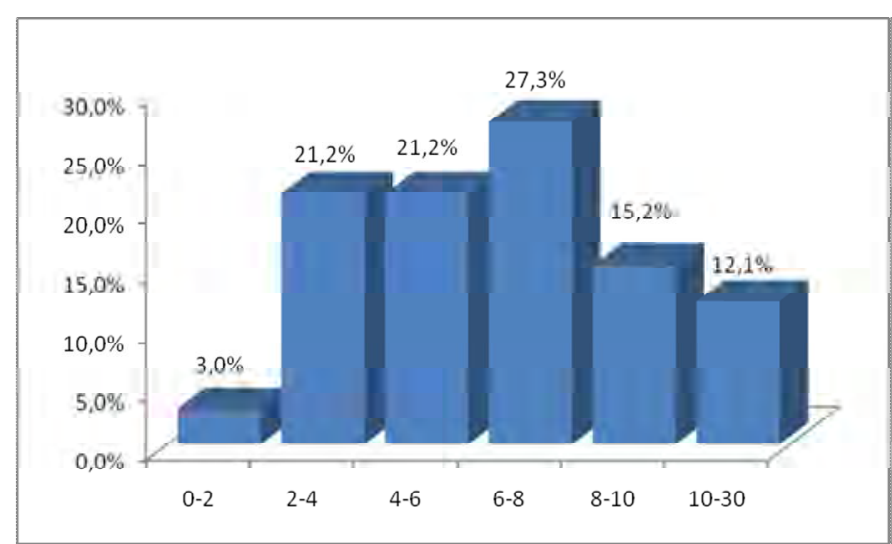

a)

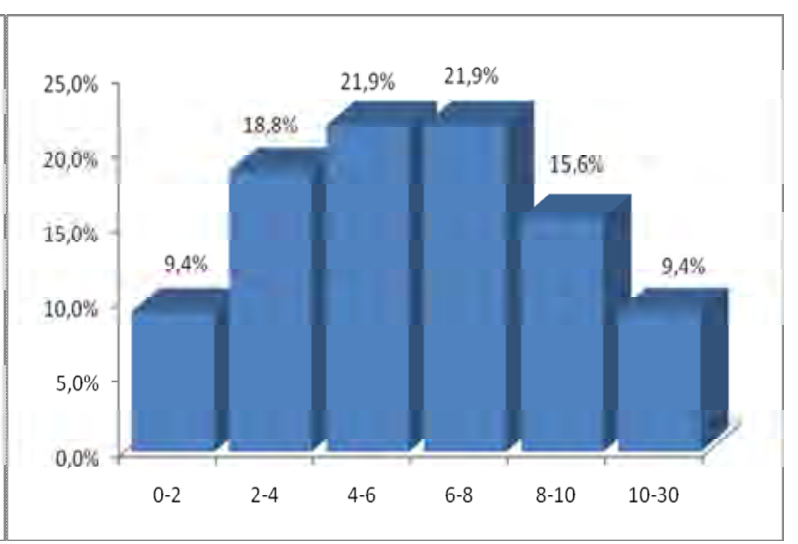

b)

Fig. 4. Pores size distribution: wet quenched coke (a) and dry quenched coke (b)

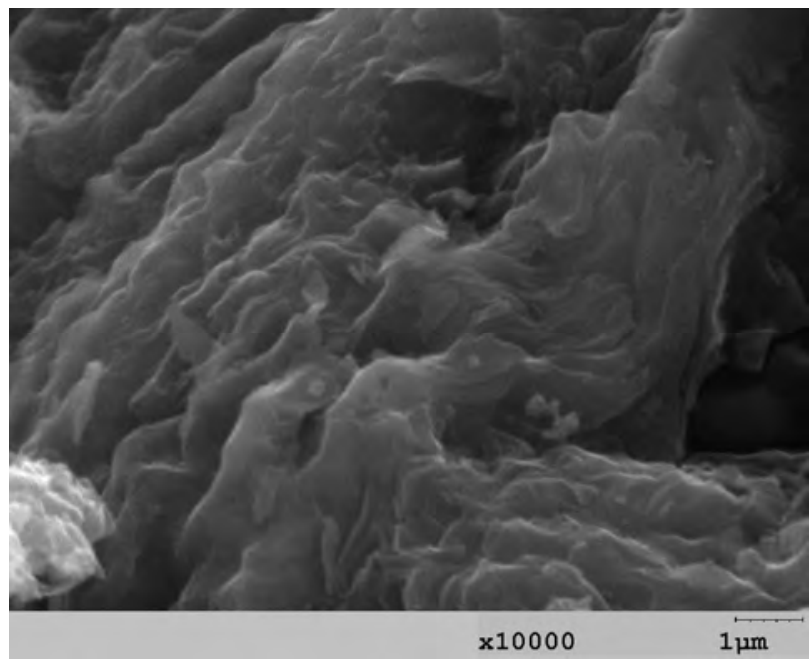

Fig. 5. Pores wall structure of wet quenching coke with $10000 x$ magnification

For quantitative assessment of coke porosity pores distribution according to size was performed using pictures with 100x magnification (Fig. 4).

Quantitative assessment of pores distribution in coke samples enabled to define that wet quenched coke has less 0-2 micron pores $(3.0 \%$, Table 4a) in comparison with dry quenched coke. Weighted average size value for wet quenched coke is 7.43 microns and for dry quenched coke it is 6.57 microns.Pores wall structure of coke samples was studied with 2500x, 5000x and 10000x magnification using SEM.

In the pictures with 5000x magnification sizes of coke structural elements were measured and calculated. In wet quenching coke elongated supramolecular formations have an average size of 0.337 micron. Ridge thickness of such formation is $0.05-0.07$ micron.

Ridge length of supramolecular formations in dry quenched coke structure of the same charge is on the

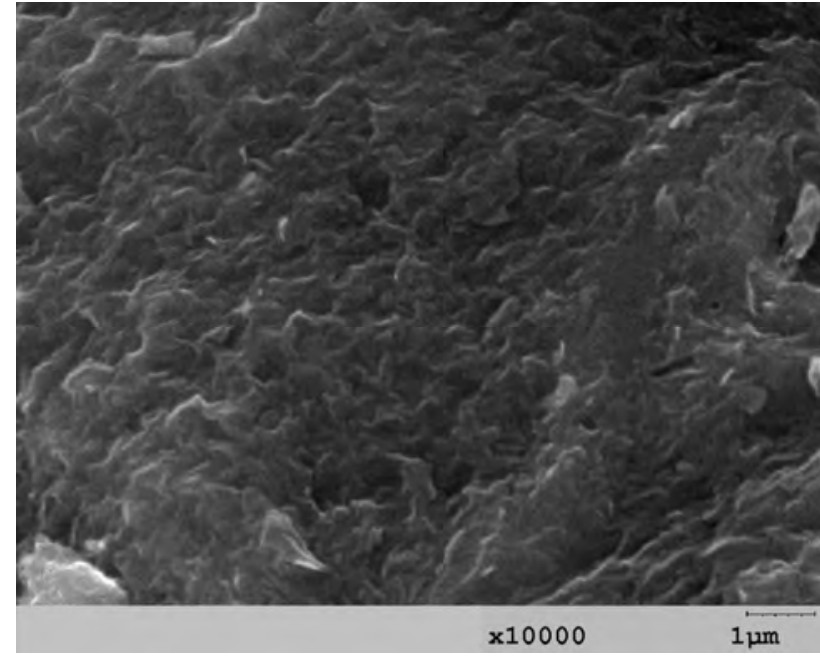

Fig. 6. Pores wall structure of dry quenching coke with 10000x magnification

average 0.67 micron. Ridge thickness is $0.5-0.8$ micron.

Figs. 5 and 6 represent pores wall surface of wet quenched and dry quenched coke with $10000 \mathrm{x}$ magnification.

As seen in Figs. 5 and 6 10000x magnification shows significant difference in coke sample structure. It can be marked that wet quenched coke pores walls have more developed surface owing to small structural elements. Dry quenched coke pores walls are characterized by bigger structural elements composed of elongated formations.

\section{Conclusions}

Application of thermogravimetry and scanning electron microscopy methods allowed to discover considerable differences in porous structure and pores 
walls forming substance structure peculiarities in wet and dry quenched coke, which could not be detected using the conventional methods.

Coke wet quenching leads to coke pores volume increase up to $60 \%$ and their average size increase up to $11.6 \%$ in comparison with dry quenched coke.

Minimum pores wall thickness of wet quenched coke is twice as little as that of dry quenched coke.

Lower reactive index of dry quenched coke (according to CRI and inflaming temperature) is resulting, in our opinion, from the fact that with dry coke quenching the most reactive part of coke structure is burned out while it remains in case of wet quenching and is additionally activated by formation of micro porous structure.

Chemical activity of wet quenched coke pores surface is much higher than that of dry quenched coke; which is confirmed by inflammation temperature and furnace loss speed data.

\section{References}

[1] Beppler E., Grospich K-Kh., Luns G. et al.: Chernye Metaly, 1999, 10.
[2] International Standard ISO 18894 Coke - Determination of coke reactivity index (CRI) and coke strength after reaction (CSR).

[3] Tamko V., Zolotariev I., Saranchuk V. et al.: Khimiya Tverdogo Topliva, 2010, 1, 15.

[4] Kovaliov E., Vasiliev Y., Kuznichenko V. et al.: Uglechim. Zh., 2009, 3-4, 24.

[5] Keltsev N.: Osnovy Absorbcionnoi Techniki. Khimiya, Moskwa 1984.

\section{ДОСЛІДЖЕННЯ ВПЛИВУ \\ СПОСОБУ ГАСІННЯ КОКСУ НА ЙОГО РЕАКЩЙНУ ЗДАТНІСТЬ}

Анотація. Приведені результати дослідження впливу способу гасіння на реакиійну здатність коксу. За допомогою методів термогравіметрії та скануючої електронної мікроскопї виявлено суттеві відмінності в пористій структурі та особливості структури коксового вуглеию, який утворює стінки пор в коксі мокрого та сухого гасіння. Встановлено, щчо вища реакиійна здатність коксу мокрого гасіння зумовлена, насамперед, вищою пористістю (на 60 \% вище, ніж у коксу сухого гасіння).

Ключові слова: кокс, структура, мокре гасіння, сухе гасіння, термогравіметрія, скануюча електронна мікроскопія, nори. 